\title{
AUTHORS' RESPONSE (DECEMBER 8, 2017) TO THE LETTER TO THE EDITOR CONCERNING THE PAPER "OCCUPATIONAL EXPOSURE TO RADON FOR UNDERGROUND TOURIST ROUTES IN POLAND: DOSES TO LUNG AND THE RISK OF DEVELOPING LUNG CANCER"
}

Dear Editor,

We thank the Revisers for their deep analysis [1] of the topic [2]. They cited many interesting and current studies that confirm such a point of view that there is negative correlation between lung cancer mortality and radon concentration or even that beneficial effects are observed for a broad range of radon concentrations. We conclude that the Revisers must be strong followers of the hormesis theory. We appreciate the effort they put into their letter. We are followers of the linear no-threshold (LNT) model as well as most of the scientific world so far. As it is well known, the LNT model has been accepted for a long time as the basis for assessing risks from the ionizing radiation. This approach has been repeatedly endorsed by the National Academy of Sciences (NAS) Committee on the Biological Effects of Ionizing Radiation (BEIR), the International Commission on Radiological Protection (ICRP), the National Council on Radiation Protection and Measurement (NCRP), and the United Nations Scientific Committee on the Effects of Atomic Radiation (UNSCEAR) [3]. And this approach has not been officially changed yet.
We are of course aware that the dose-response model for low doses radiation is uncertain, and it leaves a lot of space for speculation. Even the Bayesian analysis of many studies, that Revisers came to mind in their letter [4], „does not support the conclusion, that below $800 \mathrm{~Bq} \times \mathrm{m}^{-3}$ lung cancer risk increase," but it does not support the conclusion that below this radon concentration lung cancer risk decreases, either. Last casecontrol studies of lung cancer and indoor radon neither support any theory in $100 \%$ of certainty nor the LNT or hormesis [5,6].

All of references the Revisers cited are from articles written by researchers from various institutions all over the world, but none of them represents the position of some official organizations. We prefer to base on the model that is supported and validated by officials. Let's consider Council Directive 2013/59/Euratom of 5 December 2013 [7] that has to be implemented into the law in all European countries until 18 February 2018. This Directive among others contains the sentence: „Recent epidemiological findings from residential studies demonstrate a statistically significant increase of lung cancer risk from 
prolonged exposure to indoor radon at levels of the order of $100 \mathrm{~Bq} \times \mathrm{m}^{-3}$." It clearly indicates a statistically significant increase of lung cancer risk in radon concentration range above $100 \mathrm{~Bq} \times \mathrm{m}^{-3}$. The latest Newsletter from one of the World Health Organization (WHO) Collaborating Centre [8] indicates that key messages on the health effects from the "WHO Handbook on Indoor Radon" [9] are still valid, especially what interests us: "There is no known threshold concentration below which radon exposure presents no risk. Even low concentrations of radon can result in a small increase in the risk of lung cancer." We know that there is a growing body of experimental and epidemiological evidence that does not support the LNT model for estimating cancer risks at low doses [10]. However, most of scientists agree with the opinion that in the case of the lack of scientific knowledge about health risk of low dose radiation, the LNT approach is the most reasonable risk model at low dose levels. The linear no-threshold model is likely to remain fundamental tenet in terms of radiation protection and safety [11]. The purpose of our paper was to estimate the relative risk of lung cancer for the employees in underground tourist routes using well-known approach and taking the worst scenario.

Revisers have the right to fight for what they think is right but we think they should not submit their objections to us but rather to some suitable governmental organizations.

We think that it would be very interesting to analyze our data using both hypotheses. Therefore, we appreciate Revisers' idea to recalculate our data by using the model that takes into account the observed reduction of lung cancers in residential areas with higher radon levels and compare it with our previous calculation arising from the LNT model. If Revisers want, we can cooperate together to investigate this problem deeper.

Key words:

Radon, Cancer risk, LNT model, Hormesis, Radiation risk model, Low dose ionizing radiation

\section{REFERENCES}

1. Mortazavi SMJ, Bevelacqua JJ, Fornalski KW, Pennington CW, Welsh J, Janiak MK, et al. Letter to the editor ( $\mathrm{Au}$ gust 24, 2017) concerning the paper "Occupational exposure to radon for underground tourist routes in Poland: Doses to lung and the risk of developing lung cancer". Int J Occup Med Environ Health. 2018;31(5):703-6, https://doi.org/10.13075/ ijomeh.1896.01257.

2. Walczak K, Olszewski J, Politański P, Zmyślony M. Occupational exposure to radon for underground tourist routes in Poland: Doses to lung and the risk of developing lung cancer. Int J Occup Med Environ Health. 2017;30(5):687-94, https:// doi.org/10.13075/ijomeh.1896.00987.

3. Puskin JS. Perspective on the use of LNT for radiation protection and risk assessment by the U.S. Environmental Protection Agency. Dose Response. 2009;7(4):284-91, https://doi. org/10.2203/dose-response.09-005.Puskin.

4. Fornalski KW, Dobrzynski L. Pooled Bayesian analysis of twenty-eight studies on radon induced lung cancers. Health Phys. 2011;101(3):265-73, https://doi.org/10.1097/HP.0b013e 31821115bf.

5. Sheen S, Lee KS, Chung WY, Nam S, Kang DR. An updated review of case-control studies of lung cancer and indoor radon. Is indoor radon the risk factor for lung cancer? Ann Occup Environ Med. 2016;28:9, https://doi.org/10.1186/s40557016-0094-3.

6. Garzillo C, Pugliese M, Loffredo F, Quarto M. Indoor radon exposure and lung cancer risk: A meta-analysis of casecontrol studies. Transl Cancer Res. 2017;6(Suppl 5):934-43, https://doi.org/10.21037/tcr.2017.05.42.

7. Council Directive 2013/59/Euratom of 5 December 2013 laying down basic safety standards for protection against the dangers arising from exposure to ionising radiation, and repealing Directives 89/618/Euratom, 90/641/Euratom, 96/29/Euratom, 97/43/Euratom and 2003/122/Euratom. Off J Eur Union L 013 (Jan 17, 2014).

8. WHO Collaborating Centre for Housing and Health - BadenWürttemberg State Health Office. Radon and Health. 
WHO CC Newsletter [Internet]. Stuttgart: The Centre. No. 27; Dec 17, 2017 [cited 2017 Nov 8]. Available from: https://www.gesundheitsamt-bw.de/lga/DE/Fachinformationen/Infodienste_Newsletter/WHOCC/Documents/ No_27_2017-3_Radon.pdf.

9. World Health Organization. WHO Handbook on Indoor Radon. Geneva: The Organization; 2009.

10. Calabrese EJ, O'Connor MK. Estimating risk of low radiation doses - A critical review of the BEIR VII report and its use of the linear no-threshold (LNT) hypothesis. Radiat Res. 2014;182(5):463-74, https://doi.org/10.1667/ RR13829.1.

11. Seong KM, Seo S, Lee D, Kim M-J, Lee S-S, Park S, et al. Is the linear no-threshold dose-response paradigm still necessary for the assessment of health effects of low dose radiation? J Korean Med Sci. 2016;31(Suppl 1):10-23, https://doi.org/10.3346/jkms.2016.31.S1.S10.

Katarzyna Walczak, Jerzy Olszewski, Piotr Politański, and Marek Zmyślony

Nofer Institute of Occupational Medicine, Łódź, Poland

Department of Radiological Protection

Corresponding author: Katarzyna Walczak Nofer Institute of Occupational Medicine Department of Radiological Protection św. Teresy 8, 91-348 Łódź, Poland (e-mail: katarzyna.walczak@imp.lodz.pl)

This work is available in Open Access model and licensed under a Creative Commons Attribution-NonCommercial 3.0 Poland License - http://creativecommons.org/ licenses/by-nc/3.0/pl/deed.en. 